\title{
Perbedaan Pengaruh Penerapan Model Pembelajaran Course Review Horay dan Quantum Teaching Dilihat dari Hasil Belajar Matematika Siswa Kelas 3 SD
}

\author{
Mesti Fajar Romadhoni, Stefanus C. Relmasira \\ 292013247@student.uksw.edu, stefanus.relmasira@staff.uksw.edu \\ Universitas Kristen Satya Wacana Salatiga
}

\section{Different impacts between application of Course Review Horay and Quantum Teaching Learning Model based on Mathematics Learning Result in Third Grade Students}

\begin{abstract}
Mathematics is a numerical study that has a strong relation to countings. Learning method of Course Review Horay and Quantum Teaching could arise students' enthusiasm to get good grades. Purpose of this study was to observe differences in Mathematics learning result using learning model of Course Review Horay and Quantum Teaching. This was an experiment research type Quasi Experiment design Nonequivalent Pretest-Postest Control Grup Design. Test result between group of experiment and control showed there was an equivalent. Technic of collecting data was through observation and test. Participants of this study were students $3 A$ of SD Kristen Satya Wacana as Experiment group and students $3 B$ of SD Negeri Salatiga 6 as Control group. Data was analysed using T-test with Independent Sample t-test technique with 5\% significance level $(\alpha=0,05)$. The result showed that there was significant difference in applying Course Review Horay learning and Quantum Teaching learning model. It was proven in t-test posttest showed t-calculate was -4,642 with sig.(2tailed) adalah 0,000 <0,05 to df 48 obtained t table value $=2,011$ with t-test gain score which showed the value of $t$ calculate was -2,687 with sig.(2-tailed) 0,010<0,05 to df 48 obtained t table $=2,011$.
\end{abstract}

Keywords: Course Review Horay, Quantum Teaching, Mathematics Learning Result

Artikel ini telah diseminarkan pada Seminar Nasional dalam rangka Hari Pendidikan Nasional bertema "Keberagaman Pendidikan di Indonesia" tanggal 10 Mei 2017 di Universitas Kristen Satya Wacana Salatiga.

Received date: 27 Maret 2017

Article Info

Revised date: 25 Juni 2017

Accepted date: 19 Desember 2017

\section{PENDAHULUAN}

Matematika merupakan materi abstrak yang memiliki karakteristik berbeda dengan materi ilmu lainnya (Arnawa, 2006). Hal yang paling penting dalam belajar matematika adalah bagaimana kemampuan siswa dalam memecahkan masalah matematika. Sangat memprihatinkan ketika kita melihat hasil analisis yang dilakukan oleh PISA (Program for International Student Assessment) yang menyatakan bahwa hasil belajar siswa di Indonesia masih rendah pada bidang matematika. Padahal matematika dipandang sebagai mata pelajaran yang penting dalam memecahkan masalah di kehidupan nyata. Rendahnya hasil belajar siswa didasarkan pada pembelajaran yang masih bersifat teacher oriented, guru lebih banyak aktif dengan memberikan berbagai soal latihan dari buku paket, LKS, dan soal-soal variatif lainnya untuk dikerjakan oleh siswa.Dalam hal inilah peran guru diuji dalam merancang dan melaksanakan pembelajaran matematika yang menyenangkan bagi siswa. 
Model Pembelajaran Course Review Horay merupakan cara belajar-mengajar yang lebih menekankan pada pemahaman materi yang diajarkan guru dengan menyelesaikan soal atau pertanyaan. Model Pembelajaran Course Review Horay dapat menciptakan suasana kelas meriah dan menyenangkan karena kelompok yang dapat menjawab pertanyaan dari guru dan bernilai benar maka kelompok tersebut dapat menyuarakan horay atau yel-yel kreatif buatan sendiri. Model Pembelajaran Course Review Horay dinilai memiliki berbagai keunggulan yaitu siswa lebih semangat dalam belajar karena pembelajaran dikemas dalam suasana yang menyenangkan dan diselingi hiburan sehingga menciptakan suasana kelas yang asyik dan menyenangkan. Model Pembelajaran Quantum Teachingdapat diaplikasikan dalam diskusi kelompok maupun perorangan, sehingga guru memiliki kebebasan penuh untuk mendesain pembelajaran. Keunggulan lainya yang ditawarkan oleh Pembelajaran Quantum Teachingyaitu pembelajaran mudah diterima dan dimengerti oleh peserta didik karena dilakukan dengan tenang dan berlangsung menyenangkan. Pada Model Pembelajaran Course Review Horaypembelajaran dikemas dengan sedikit hiburan didalamnya, sehingga pembelajaran menjadi menarik dan mendorong siswa untuk dapat terjun langsung ke dalamnya serta melatih kerjasama siswa. Dengan begitu penyampaian teori tidak akan monoton, sehingga dapat menarik perhatian siswa untuk fokus pada pelajaran tersebut sehingga tingkat pemahaman siswa menjadi lebih optimal.

Harianto (2013) dalam penelitiannya yang berjudul Pengaruh Strategi Pembelajaran Course Review Horay Menggunakan Puzzle Terhadap Hasil Belajar Siswa pada Standar Kompetensi menerapkan Dasar-Dasar Elektronika di SMK menunjukkan rata-rata hasil belajar kelas eksperimen sebesar 79,1 dan nilai rata-rata kelas kontrol sebesar 76,1 Dan perhitungan menggunakan uji $\mathrm{t}$ diperoleh $t_{\text {hitung }}=2,5>t_{\text {tabel }}=1,67$. Berdasarkan hasil penelitian diatas maka dapat disimpulkan bahwa kelas yang menggunakan pembelajaran Course Review Horay menggunakan puzzle mempunyai nilai hasil belajar yang lebih baik daripada kelas yang menggunakan pembelajaran kooperatif.

Rochayati (2007) dalam penelitiannya yang berjudul Pengaruh Metode Quantum Teaching dan Quantum Learning Terhadap Prestasi Belajar Matematika Ditinjau Dari Aktivitas Belajar Siswa (Pada Siswa Kelas III SD Negeri 20 Kota Madya Banda Aceh) menunjukkan bahwa pembelajaran matematika dengan metode Quantum Teaching dan Quantum Learning dan Aktivitas belajar siswa yang tinggi memberikanpengaruh yang positif terhadap prestasi belajar matematika siswa, sehingga dapat meningkatkan prestasi belajar matematika pada pokok bahasan penjumlahan dan pengurangan. Pengujian prasyarat analisis menggunakan uji normalitas dan uji homogenitas, sedangkan teknik analisis datanya adalah analisis variansi dua jalan dengan sel tak sama. Berdasarkan hasil penelitian ini, dengan taraf signifikansi 5\% dapat disimpulkan bahwa: (1) Terdapat pengaruh metode Quantum Teaching dan Quantum Learningterhadap prestasi belajar matematika dengan Fhitung = 20,65 (2) Terdapat pengaruh aktivitas belajar siswa terhadap prestasi belajar matematika dengan Fhitung $=8,34$ (3) Tidak terdapat interaksi antara metode pembelajaran yang berbeda dan aktivitas belajar siswa terhadap prestasi belajar matematika dengan Fhitung = 2,27. Berdasarkan dari hasil penelitian diatas tampak jelas bahwa model pembelajaran Course Review Horay dapat meningkatkan hasil belajar siswa dan model pembelajaran Quantum Teaching juga dapat meningkatkan hasil belajar siswa.

Penelitian ini dilatar belakangi oleh hasil belajar matematika pada materi konversi satuan waktu yang masih rendah. Siswa masih mengganggap bahwa matematika merupakan pelajaran yang sulit, guru lebih menekankan siswa untuk terus berlatih soal, memang baik siswa dituntut untuk terus latihan, namun bila pelajaran matematika tidak diselingi hiburan atau sesuatu yang menyenangkan maka pembelajaran matematika menjadi sangat membosankan, guru lebih banyak aktif untuk memberi soal-soal latihan tanpa adanya unsur yang menyenangkan didalamnya, untuk itulah peneliti mencoba menerapkan model 
pembelajaran Course Review Horay di kelas 3A SD Kristen Satya Wacana Salatiga sebagai kelas eksperimen dan peneliti menerapkan model pembelajaran Quantum Teaching di SD Negeri Salatiga 6 sebagai kelas kontrol. Penelitian ini perlu dilakukan dengan tujuan agar pembelajaran matematika di kelas rendah menjadi menyenangkan dan membuat siswa terlibat aktif sehingga diharapkan terjadi peningkatan hasil belajar matematika, dan tentu saja agar peneliti mengetahui perbedaan hasil belajar matematika setelah diberikan perlakuan model pembelajaran Course Review Horay dan Quantum Teaching.

\section{KAJIAN PUSTAKA}

Matematika merupakan ilmu tentang bilangan dan berhubungan erat dengan hitung menghitung melalui cara berfikir untuk membuktikan apakah suatu pernyataan benar atau salah dengan menggunakan logika. Misalnya dalam hal jual beli, menghitung laba rugi, mengukur luas lapangan, menghitung jarak, menghitung persen, mengukur besar sudut dan semua hal yang berhubungan dengan membuktikan kebenaran, maka sejauh itulah kita membutuhkan matematika untuk menyelesaikan persoalan tersebut.Pada hakikatnya pembelajaran matematika merupakan proses yang sengaja dirancang dengan tujuan untuk menciptakan suasana lingkungan memungkinkan seseorang melaksanakan kegiatan matematika, dan proses tersebut berpusat pada guru mengajar matematika (Wahyudi dan Kriswandari, 2013). Pembelajaran di SD bertujuan untuk mengembangkan kemampuan siswa, khususnya dalam hal sebagai mana telah dituangkan dalam Permendiknas No.22 Tahun 2006, yaitu:

1. Memahami konsep matematika, menjelaskan keterkaitan antarkonsep.

2. Menggunakan penalaran pada pola dan sifat, melakukan manipulasi Matematika dalam membuat generalisasi, menyusun bukti, atau menjelaskan gagasan dan pernyataan Matematika.

3. Memecahkan masalah yang meliputi kemampuan memahami masalah, merancang model Matematika, menyelesaikan model dan menafsirkan solusi yang diperoleh.

4. Mengkomunikasikan gagasan dalam simbol, tabel, diagram, atau media lain untuk memperjelas keadaan atau masalah.

5. Memiliki sikap menghargai kegunaan Matematika dalam kehidupan, yaitu memiliki rasa ingin tahu, perhatian, dan minat dalam mempelajari matematika, serta sikap ulet dan percaya diri dalam pemecahan masalah.

Dengan tujuan yang telah dipaparkan maka Matematika perlu dipelajari oleh siswa SD/MI karena Matematika sangat berguna dalam memecahkan masalah di kehidupan sehari-hari.

Belajar merupakan suatu proses perubahan yaitu perubahan tingkah laku sebagai hasil dari interaksi dengan lingkungannya dalam memenuhi kebutuhan hidupnya (Slameto, 2010). Selanjutnya Gagne (dalam Slameto, 2010) memberikan 2 pengertian belajar, yaitu:

1. Belajar merupakan proses untuk memperoleh motivasi dalam pengetahuan, keterampilan, kebiasaan, dan tingkah laku; dan

2. Belajar adalah penguasaan pengetahuan atau keterampilan yang diperoleh dari intruksi. Dalam hal belajar pasti selalu terjadi perubahan tingkah laku dan juga perubahan cara menanggapi lingkungan, dari perubahan itulah maka kita dapat melihat hasil dari perubahan melalui hasil belajar. Peneliti menyimpulkan bahwa hasil belajar matematika merupakan perubahan tingkah laku yang dilakukan dengan cara berfikir logis untuk memecahkan masalah dalam kehidupan sehari-hari. Hasil belajar matematika digunakan guru untuk mengukur pemahaman siswa setelah siswa menerima materi pelajaran. 
Isjoni (2010) mengemukakan bahwa pembelajaran kooperatif dapat diartikan belajar yang dilakukan secara bersama-sama, saling membantu antara satu dan yang lain dalam belajar dan memastikan bahwa setiap orang dalam kelompok mencapai tujuan atau tugas yang telah ditentukan sebelumnya. Upaya belajar merupakan segala aktivitas yang dilakukan siswa untuk meningkatkan kemampuan entah kemampuan yang sudah ada ataupun kemampuan baru dalam hal kemampuan kognitif, afektif maupun kemampuan psikomotorik. Dalam melakukan upaya belajar tak akan lepas dari aktivitas belajar yang dilakukan dalam kelompok sehingga siswa dapat saling bertukar ide atau gagasan, belajar bersama, menemukan solusi dari suatu masalah bersama-sama, dan saling berbagi pengalaman. Peneliti menyimpulkan bahwa pembelajaran kooperatif adalah kegiatan belajar yang dilakukan siswa dalam bentuk kelompok kecil atau tim untuk saling bekerjasama, saling membantu, saling bertukar ide atau gagasan dalam mempelajari materi pelajaran maupun dalam memecahkan suatu persoalan dengan tujuan dapat mencapai tujuan pembelajaran yang diharapkan, tentu saja hal ini tidak terlepas dari peran guru sebagai fasilitator pendidikan.

Pembelajaran kooperatif memiliki beberapa model, salah satunya adalah Course Review Horay. Model Pembelajaran Course Review Horaydapat mendorong siswa untuk ikut aktif dalam belajar. Model Pembelajaran Course Review Horaymerupakan cara belajarmengajar yang lebih menekankan pada pemahaman materi yang diajarkan guru dengan menyelesaikan soal atau pertanyaan (Harianto, 2012). Model PembelajaranCourse Review Horaydapat menciptakan susana kelas menjadi meriah dan menyenangkan karena setiap siswa yang menjawab pertanyaan dengan benar diwajibkan berteriak "horay" atau yel-yel lain yang disukai. Menurut Suyatno (2009) dan Dwitantra (2010) untuk membuat pembelajaran model Course Review Horaylebih menarik dan menyenangkan, maka dapat mengikuti langkah-langkah berikut ini:

1. Guru menyampaikan kompetensi yang ingin dicapai.

2. Guru mendemonstrasikan atau menyajikan materi.

3. Guru memberikan kesempatan siswa untuk tanya jawab.

4. Guru membagi siswa kedalam beberapa kelompok (terdiri dari 3-4 orang).

5. Guru membuat kotak sejumlah 9 buah kotak ke dalam sebuah kertas yang dibagikan kepada masing-masing kelompok.

6. Guru membaca soal secara acak dan siswa menuliskan jawabannya di dalam kotak yang nomornya disebutkan guru dan langsung didiskusikan.

7. Kelompok yang dapat menjawab pertanyaan dari guru dengan benar harus menempelkan simbol kelompoknya di kotak yang sudah terjawab.

8. Perhitungan skor yang didapatkan masing-masing kelompok didasarkan pada simbol kelompok yang membentuk vertikal, horizontal, maupun diagonal.

9. Kelompok yang berhasil menempelkan simbol hingga berbentuk vertikal, horizontal, maupun diagonal boleh berteriak horay atau yel-yel lainnya.

10. Penilaian kelompok didasarkan pada perhitungan jawaban benar dan teriakan horay yang diperoleh setiap kelompok.

11. Guru memberikan reward pada kelompok yang memperoleh nilai tertinggi atau yang paling sering berteriak horay.

Model pembelajaran Course Review Horay dapat membuat pembelajaran menarik dan mendorong siswa aktif terlibat dalam pembelajaran, suasana pembelajaran menyenangkan karena diselingi hiburan, terjadi komunikasi dua arah, dan tidak membutuhkan biaya yang mahal dalam penerapannya.

Sejalan dengan perkembangan dunia pendidikan, ditemukan sebuah pendekatan pengajaran yang disebut Quantum Teaching. Quantum Teachingberawal dari sebuah upaya 
Dr. Georgi Lozanov, pendidikan asal Bulgaria yang bereksperimen dengan suggestology. Prinsipnya, sugesti dapat mempengaruhi hasil belajar (Thobroni, 2016).

Quantum merupakan istilah yang banyak digunakan dalam ilmu fisika, namun sekarang menjadi populer setelah banyak istilah-istilah yang muncul seperti: quantum learning, quantum business, dan quantum teaching. Quantum artinya interaksi yang mengubah energi menjadi cahaya (Thobroni, 2016). Quantum Teaching adalah model pembelajaran dengan suasana yang menyenangkan dengan pendampingan unsur seni dan pencapaian yang terarah maka Quantum Teaching dapat diterapkan pada mata pelajaran apapun.

Menurut Bobbi DePorter (2000) model pembelajaran Quantum Teaching mempunyai beberapa sintak yaitu:

1. Guru harus mampu menumbuhkan minat belajar kepada siswa dan dalam hal ini guru mampu menumbuhkan minat belajar kepada siswa agar kemampuan siswa dapat meningkat.

2. Dalam penyampaian materi pembelajaran guru harus dapat memberikan contoh yang mudah dimengerti dan dipahami oleh siswa.

3. Guru dalam menyampaikan materi harus menggunakan kata dan kalimat yang benar dan mudah dimengerti oleh siswa sehingga siswa akan mudah untuk menerima materi pelajaran dengan baik.

4. Dalam menyampaikan materi, guru dapat menggunakan media atau alat peraga dengan maksud supaya siswa dapat dengan mudah memahami dan mengerti materi pelajaran yang diberikan.

5. Guru dapat memberikan ringkasan atau rangkuman materi pelajaran kepada siswa supaya siswa dapat dengan mudah mengingat materi pelajaran yang telah diberikan.

6. Guru dapat memberikan penghargaan atau pujian kepada siswa atas segala usaha dan kerja keras mereka dalam menyelesaikan tugas yang telah diberikan sehingga siswa merasa diakui setiap usahanya. Berdasarkan penjelasan tersebut siswa sama-sama belajar dengan suasana yang menyenangkan, guru menggunakan alat peraga atau alat bantu belajar, siswa dapat bekerja sama dalam memecahkan persoalan matematika, maka dengan menggunakan model pembelajaran Course Review Horay dan Quantum Teachingdiharapkan dapat berpengaruh positif terhadap hasil belajar siswa.

\section{METODE PENELITIAN}

Subjek penelitian dalam penelitian ini adalah semua anggota populasi merupakan sampel. Sampel diambil dari kelas 3A SD Kristen Satya Wacana yang beralamatkan di Jln. Yos Sudarso No.1 dan kelas 3B SD Negeri Salatiga 6 yang beralamat di Jln. Kartini No.26. Kedua sekolah ini berada di daerah yang sama yaitu Kecamatan Sidorejo, Kota Salatiga. Kedua sekolah ini memiliki kelas paralel dan sudah menerapkan Kurikulum 2013 dalam proses belajar mengajar. Berdasarkan persamaan yang telah dikemukakan, peneliti akhirnya memilih untuk melakukan penelitian di 2 SD tersebut. Kegiatan penelitian ini dilaksanakan pada bulan Februari 2017 pada semester genap. Penelitian ini merupakan penelitian eksperimen dengan jenis Quasi Eksperimentdengan desain penelitian Nonequivalent PretestPosttest Control Group Design. Variabel dalam penelitian ini adalah model pembelajaran Course Review Horaydan model pembelajaran Quantum Teaching. Teknik dan Instrumen pengumpulan data menggunakan pretest dan posttest dan dilakukan observasi kelas.Uji coba instrumen dalam penelitian ini menggunakan uji validitas soal dan uji reliabilitas soal tes. Setelah itu dilakukan uji hipotesis untuk menguji signifikansi perbedaan mean antara kelas eksperimen dan kelas kontrol menggunakan uji dua sampel tidak berhubungan (IndependentSamples $T$ test). Uji t digunakan untuk melihat perbedaan rata-rata hasil belajar matematika 
antara siswa yang diberi perlakuan model pembelajaran Course Review Horaydengan siswa yang diberi perlakuan model pembelajaran Quantum Teaching.

Hipotesis statistika dapat dirumuskan sebagai berikut:

1. $\mathrm{H}_{0}: \mu_{\text {Course Review Horay }}=\mu_{Q \text { uantum Teaching }}$

Tidak terdapat perbedaan yang signifikan antarmodel pembelajaran Course Review Horay dan model pembelajaran Quantum Teachingdilihat dari hasil belajar matematika siswa kelas 3 Semester II Tahun Ajaran 2016/2017 di SD Kristen Satya Wacana dan SD Negeri Salatiga 6.

2. $\mathrm{H}_{1}: \mu_{\text {Course Review Horay }} \neq \mu_{\text {Quantum Teaching }}$

Terdapat perbedaan hasil belajar yang signifikan dalam penerapan model pembelajaran Course Review Horay dan model pembelajaran Quantum Teaching dilihat dari hasil belajar matematika siswa kelas 3 Semester II Tahun Ajaran 2016/2017 di SD Kristen Satya Wacana dan SD Negeri Salatiga 6.

\section{HASIL PENELITIAN DAN PEMBAHASAN Hasil Observasi Pembelajaran Matematika di kelas 3A SD Kristen Satya Wacana}

Topik yang digunakan dalam penelitian ini adalah materi konversi waktu yang didasarkan pada Kompetensi Dasar 3.9. Mengenal hubungan antarsatuan waktu, antarsatuan panjang, dan antarsatuan berat yang biasa digunakan dalam kehidupan seharihari(Kemendikbud,2015). Sedangkan indikator pencapaian kompetensinya adalah mengonversi sebuah satuan waktu dengan satuan waktu lainnya.

Berdasarkan hasil observasi guru dalam melaksanakan pembelajaran yang sesuai sintak pada pertemuan pertama dan kedua telah mencapai 92\%, 8\% tidak terlaksana karena alokasi waktu yang dipakai tersita lama untuk membuat yel-yel sehingga kelas menjadi riuh, sedangkan pada pertemuan ketiga sudah mencapai $100 \%$ dengan catatan alokasi waktu sudah baik dan siswa kondusif dalam mengikuti pembelajaran.

Sesuai dengan data yang diambil, bahwa nilai rata-rata kelas eksperimen (nilai pretest) sebelum proses pembelajaran dengan menggunakan model pembelajaran Course Review Horay sebesar 33,68 dengan standar deviasi 14,384. Hal lain yang tampak adalah skor tertinggi yang dicapai pada pretestadalah 63 dan skor terendahnya adalah 13. Sedangkan pada posttest skor tertinggi yang berhasil dicapai adalah 90 dan skor terendahnya adalah 13 . Jumlah siswa yang mengikuti pretest dan posttest ini sebanyak 25 siswa.

\section{Hasil Observasi Pembelajaran Matematika di kelas 3B SD Negeri Salatiga 6}

Topik yang digunakan dalam penelitian ini adalah materi konversi waktu yang didasarkan pada Kompetensi Dasar 3.9. Mengenal hubungan antarsatuan waktu, antarsatuan panjang, dan antarsatuan berat yang biasa digunakan dalam kehidupan sehari-hari (Kemendikbud,2015). Sedangkan indikator pencapaian kompetensinya adalah mengonversi sebuah satuan waktu dengan satuan waktu lainnya.

Berdasarkan hasil observasi guru dalam melaksanakan pembelajaran yang sesuai sintaks pada pertemuan pertama telah mencapai $82 \%$, 28\% tidak terlaksana dikarenakan pengaturan waktu yang masih perlu diperhatikan dan siswa belum disebar menjadi beberapa kelompok, sehingga masih bekerja secara individu pada pertemuan ini. Pada pertemuan kedua dan ketiga telah mencapai $100 \%$ dengan catatan kegiatan pembelajaran terlaksana dengan baik dan siswa mengikuti pembelajaran dengan kondusif.

Sesuai dengan data yang diambil, bahwa nilai rata-rata kelas eksperimen (nilai pretest) sebelum proses pembelajaran menggunakan model pembelajaran Quantum Teaching sebesar 45,84 dengan standar deviasi 15,561. Hal lain yang tampak adalah skor tertinggi yang 
berhasil dicapai adalah 80 dan skor terendahnya adalah 20. Jumlah siswa yang mengikuti pretest dan posttest sebanyak 25 siswa.

\section{Deskripsi Komparasi Hasil Pengukuran}

Deskripsi komparasi ini menyajikan perbandingan hasil pengukuran dari kelas eksperimen dan kelas kontrol pada masing-masing SD berdasarkan rata-rata nilai pretest dan nilai posttest. Nilai rata-rata pada tahap pengukuran awal yang ditunjukkan adanya selisih skor antara kelas eksperimen dan kelas kontrol sebesar 12,16 yang menyatakan bahwa nilai rata-rata kelas kontrol lebih unggul. Sedangkan pada tahap pengukuran akhir juga terdapat perbedaan nilai rata-rata yang ditunjukkan adanya selisih skor antara kelas eksperimen dan kelas kontrol sebesar 26,08 dimana kelas kontrol lebih unggul.

Pada tahap pengukuran awal kelas eksperimen memperoleh mean sebesar 33,68 dan pada tahap pengukuran akhir kelas eksperimen memperoleh mean sebesar 43,88 sehingga diperoleh gain score sebesar 10,08. Sedangkan pada tahap pengukuran awal kelas kontrol memperoleh mean sebesar 45,84 dan pada tahap pengukuran akhir kelas kontrol memperoleh mean sebesar 69,96 sehingga diperoleh gain score sebesar 24,24. Secara ringkas deskripsi komparasi hasil pengukuran dapat dilihat pada gambar 1 berikut.

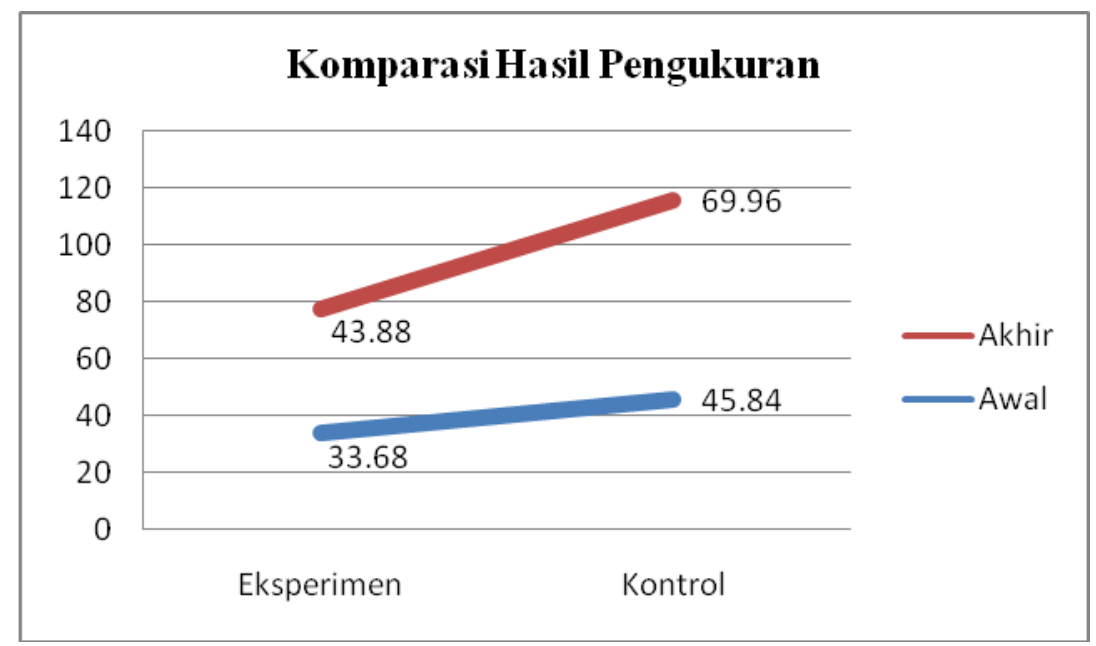

Gambar 1.

Grafik Deskripsi KomparasiHasil Pengukuran Kelas Eksperimen dan Kelas Kontrol

\section{Hasil Uji Perbedaan Rata-rata Hasil Belajar Menggunakan Model Pembelajaran Course Review Horaydan Quantum Teaching}

Perhitungan uji t dilakukan dengan menggunakan Independent-Samples $T$ testdengan melakukan uji prasyarat dan uji hipotesis terlebih dahulu. Uji prasyarat terdiri atas uji normalitas dan homogenitas. Uji normalitas yang sudah dilakukan menunjukkan bahwa nilai Sig. hasil pretest-posttest kelas eksperimen dan kelas kontrol adalah 0,197 dan 0,094. Karena nilai signifikansi/probabilitas data-data tersebut > 0,05 maka dapat disimpulkan bahwa populasi data hasil pretest-posttest kelas eskperimen dan kelas kontrol berdistribusi normal. Sedangkan uji homogenitas hasil pretest-posttest kelas eksperimen dan kelas kontrol adalah 0,979 dan 0,213. Karena nilai probabilitas populasi data > 0,05 maka dapat dikatakan bahwa data nilai pretest-posttest kelas eksperimen dan kelas kontrol memiliki varian yang sama atau homogen.

Berdasarkan hasil uji normalitas yang menunjukkan bahwa persebaran data posttest berdistribusi normal dan uji homogenitas menunjukkan bahwa data posttesthomogen, maka dengan demikian populasi data posttest dapat digunakan untuk uji beda t-test sebagai acuan 
menguji hipotesis ada atau tidak ada perbedaan rata-rata nilai posttest yang signifikan antara kelas eksperimen dan kelas kontrol. Analisis uji beda rata-rata posttestkelas eksperimen dan kelas kontrol dapat dilihat pada tabel 1 berikut.

Tabel 1.

Hasil uji t nilai posttest kelas eksperimen dan kelas kontrol

Independent Samples Test

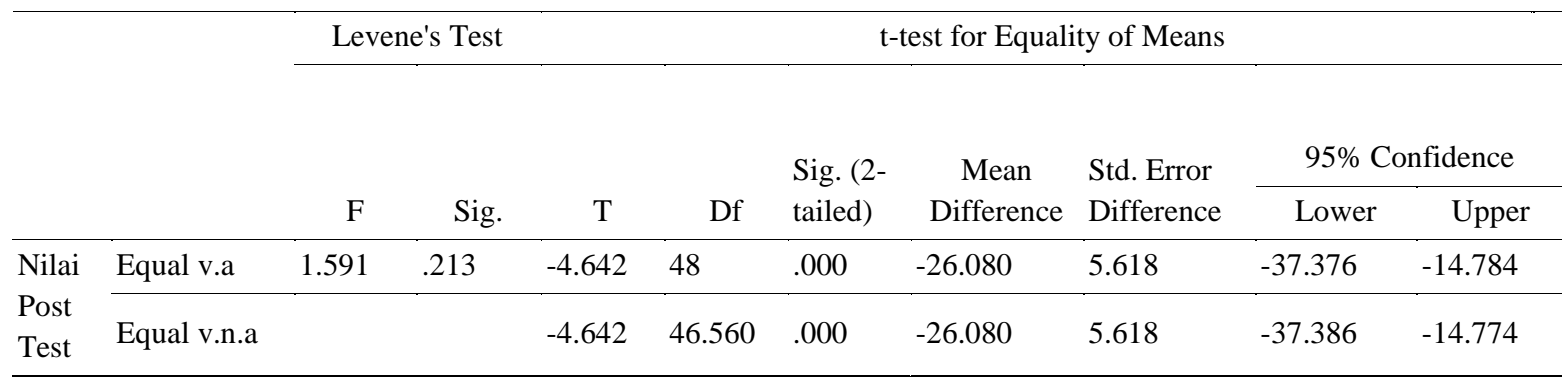

Analisis uji beda t-testmenggunakan equal variance assummed(asumsi varian sama).Dari tabel 1 dapat dilihat bahwa nilai t hitung sebesar -4,642 dengan probabilitas signifikan $0,000<0,05$ dan pada df 48 . Dikarenakan nilai t hitung negatif: ada perbedaan bermakna apabila $t_{\text {hitung }}<t_{\text {tabel }}(-4.642<2,011)$ dan nilai sig. 0,000 dengan kriteria jika nilai sig. lebih kecil dari taraf signifikansi yang digunakan yaitu $0,05(0,000<0,05)$, maka $\mathrm{H}_{1}$ diterima dan $\mathrm{H}_{0}$ ditolak sehingga disimpulkan terdapat perbedaan hasil belajar yang signifikan dalam penerapan model pembelajaran Course Review Horay dan model pembelajaran Quantum Teaching dilihat dari hasil belajar matematika siswa kelas 3 Semester II Tahun Ajaran 2016/2017 di SD Kristen Satya Wacana dan SD Negeri Salatiga 6. Dari hasi uji gain score diperoleh nilai t hitung adalah -2,687 dengan probabilitas signifikan nilai sig. $0,010<0,05$ pada df 48 . Dikarenakan nilai t hitung negatif: ada perbedaan bermakna apabila $t_{\text {hitung }}<t_{\text {tabel }}(-2,687<2,011)$ dan nilai sig. 0,010 dengan kriteria jika nilai sig. lebih kecil dari taraf signifikansi yang digunakan yaitu $0,05(0,010<0,05)$, maka dapat disimpulkan terdapat perbedaan gain scorehasil belajaryang signifikan antara kelas eksperimen dan kelas kontrol. Uji beda rata-rata gain scorekelas eksperimen dan kelas kontrol dapat dilihat pada tabel 2 berikut.

Tabel 2.

Uji beda rata-rata gain scorekelas eksperimen dan kelas kontrol

\begin{tabular}{|c|c|c|c|c|c|c|c|c|c|c|}
\hline \multicolumn{11}{|c|}{ Independent Samples Test } \\
\hline & & $\begin{array}{r}\text { Levene's ' } \\
\text { Equali } \\
\text { Variar }\end{array}$ & $\begin{array}{l}\text { est for } \\
\text { y of } \\
\text { ces }\end{array}$ & & & $\mathrm{t}$-test $\mathrm{f}$ & or Equality of & Means & & \\
\hline & & \multirow[b]{2}{*}{$\mathrm{F}$} & \multirow[b]{2}{*}{ Sig. } & \multirow[b]{2}{*}{$\mathrm{T}$} & \multirow[b]{2}{*}{ Df } & \multirow{2}{*}{$\begin{array}{l}\text { Sig. }(2- \\
\text { tailed) }\end{array}$} & \multirow{2}{*}{$\begin{array}{c}\text { Mean } \\
\text { Difference }\end{array}$} & \multirow{2}{*}{$\begin{array}{l}\text { Std. Error } \\
\text { Difference }\end{array}$} & \multicolumn{2}{|c|}{$\begin{array}{l}\text { 95\% Confidence } \\
\text { Interval of the } \\
\text { Difference }\end{array}$} \\
\hline & & & & & & & & & Lower & Upper \\
\hline \multirow[t]{2}{*}{ selisih } & $\begin{array}{l}\text { Equal variances } \\
\text { assumed }\end{array}$ & .078 & .781 & -2.687 & 48 & .010 & -14.160 & 5.269 & -24.754 & -3.566 \\
\hline & $\begin{array}{l}\text { Equal variances not } \\
\text { assumed }\end{array}$ & & & -2.687 & 47.995 & .010 & -14.160 & 5.269 & -24.754 & -3.566 \\
\hline
\end{tabular}

Berdasarkan tabel 2 hasil $\mathrm{F}$ hitung levene's testsebesar 0,078 dengan probabilitas $0,781>0,05$, maka dapat disimpulkan bahwa kedua populasi memiliki variance sama atau 
dengan kedua kelas homogen. Dengan demikian analisis uji beda t-test harus menggunakan asumsi equal variance assummed dari tabel 2 terlihat bahwa nilai t adalah -2,687 dengan probabilitas signifikan $0,010<0,05$ dan pada df 48 . Df pada uji t adalah $\mathrm{N}-2$, yaitu $50-2=48$, maka nilai $t_{\text {tabel }}$ menggunakan tabel $\mathrm{t}$ dihitung dengan bantuan Microsoft Exceldengan rumus $=\operatorname{TINV}(0,05 ; 48)$ sehingga diperoleh nilai $t_{t a b e l}=2,011$. Apabila nilai t positif: ada perbedaan bermakna apabila $t_{\text {hitung }}>t_{\text {tabel }}$. Apabila nilai t hitung negatif: ada perbedaan bermakna apabila $t_{\text {hitung }}<t_{\text {tabel }}(-2.687<2,011)$ dan nilai sig. 0,010 dengan kriteria jika nilai sig. lebih kecil dari taraf signifikansi yang digunakan yaitu $0,05(0,010<0,05)$, maka dapat disimpulkan terdapat perbedaan bermakna rata-rata gain scorehasil belajar siswa antara kelas eksperimen dan kelas kontrol.

\section{Hasil Uji Hipotesis}

Hasil uji t (uji beda rata-rata) terhadap nilai posttestkelompok eksperimen dan kontrol dapat dijadikan dasar untuk menguji hipotesis. Hipotesis yang telah dirumuskan adalah sebagai berikut.

1. $\mathrm{H}_{0}$ :Tidak terdapat perbedaan yang signifikan antarmodel pembelajaran Course Review Horay dan model pembelajaran Quantum Teachingdilihat dari hasil belajar matematika siswa kelas 3 Semester II Tahun Ajaran 2016/2017 di SD Kristen Satya Wacana dan SD Negeri Salatiga 6.

2. $\mathrm{H}_{1}$ :Terdapat perbedaan hasil belajar yang signifikan dalam penerapan model pembelajaran Course Review Horay dan model pembelajaran Quantum Teaching dilihat dari hasil belajar matematika siswa kelas 3 Semester II Tahun Ajaran 2016/2017 di SD Kristen Satya Wacana dan SD Negeri Salatiga 6.

Berdasarkan uji t (uji beda rata-rata) yang telah dilakukan terhadap nilai posttest kelompok eksperimen dan kontrol di kedua SD diperoleh hasil yaitu nilai t-test sebesar 4,642 dengan probabilitas signifikan $0,000<0,05$ dan pada df 48. Dikarenakan nilai t hitung negatif: ada perbedaan bermakna apabila $t_{\text {hitung }}<t_{\text {tabel }}(-4.642<2,011)$ dan nilai sig.0,000 dengan kriteria jika nilai sig. lebih kecil dari taraf signifikansi yang digunakan yaitu 0,05 $(0,000<0,05)$, maka H1diterima dan Hoditolak sehingga disimpulkan terdapat perbedaan hasil belajar yang signifikan dalam penerapan model pembelajaran Course Review Horay dan model pembelajaran Quantum Teaching dilihat dari hasil belajar matematika siswa kelas 3 Semester II Tahun Ajaran 2016/2017 di SD Kristen Satya Wacana dan SD Negeri Salatiga 6.

\section{Pembahasan}

Rata-rata nilai pretest siswa SD Kristen Satya Wacana sebagai kelas eksperimen pada pembelajaran matematika mencapai 33,68 dan rata-rata nilai siswa SD Negeri Salatiga 6 sebagai kelas kontrol pada pembelajaran matematika mencapai 43,88, kedua kelas ini samasama masuk ke dalam kategori cukup. Berdasarkan tingkat rata-rata hasil belajar siswa SD Kristen Satya Wacana sebagai kelas eksperimen setelah diberi perlakuan dengan menggunakan model pembelajaran Course Review Horay mencapai 45,84 termasuk dalam kategori baik, sedangkan rata-rata nilai siswa SD Negeri Salatiga 6 sebagai kelas kontrol setelah diberi perlakuan model pembelajaran Quantum Teaching pada pembelajaran matematika mencapai 69,96 dan masuk dalam kategori sangat baik.

Dari uji $t$-test hasil hitung menunjukkan -4,642 dengan probabilitas signifikan 0,000< 0,05 artinya rata-rata nilai sebelum diberikan perlakuan model pembelajaran Course Review Horay dan Quantum Teachingberbeda dengan rata-rata nilai setelah diberi perlakuan. Ratarata nilai hasil belajar kelas kontrol lebih tinggi jika dibandingkan dengan rata-rata nilai siswa 
kelas eksperimen. Hal ini dapat dilihat dari perbedaan rata-rata nilai siswa kelas kontrol sebesar 69,96 dan kelas eksperimen sebesar 45,84.

Hasil penelitian yang dilakukan peneliti dibandingkan dengan penelitian yang dilakukan oleh I Nym Adi Kurniawan, I Md Suara dan I. B. Surya Manuaba (2014) yang menyimpulkan bahwa model Quantum Teaching berbantuan media audio berpengaruh positif dan signifikan terhadap hasil belajar IPS siswa kelas V semester 1 SD Gugus 7 Sukawati, Kabupaten Gianyar Tahun Ajaran 2013/2014. Dari hasil analisis data yang diperoleh peneliti menggunakan uji-t dengan taraf signifikan 0,000 $<0,05$ dengan df 48 dan $t_{\text {tabel }}$ sebesar 2,011, sehingga $t_{\text {hitung }}<t_{\text {tabel }}(-4.642<2,011)$ sedangkan penelitian sebelumnya menunjukkan tingkat signifikan $5 \%(\alpha=0,05)$ dengan $\mathrm{dk}=63$ dan $t_{\text {tabel }}$ sebesar 2,00, sehingga $t_{\text {hitung }}>t_{\text {tabel }}(2,72>2,00)$. Adapun persamaan yang dimiliki pada penelitian ini yaitu penelitian ini sama-sama menggunakan model pembelajaran Quantum Teaching namun perbedaan pada mata pelajaran dan kelas yang diambil dimana peneliti sebelumnya mengambil mata pelajaran IPS kelas V sedangkan penelitian yang dilakukan peneliti mengambil mata pelajaran matematika kelas III.

Hasil penelitian Pratiwi, L. (2011) yang berjudul "Penerapan model course review horay (CRH) untuk meningkatkan pembelajaran IPA siswa kelas IV SDN Merjosari 1 Malang. Penerapan model course review horay (CRH) untuk meningkatkan pembelajaran IPA siswa kelas IV SDN Merjosari 1 Malang" menumukan hasil sejalan dengan penelitian ini; Hasil belajar juga meningkat dari rata-rata 58,78 dan ketuntasan kelas 43,75\% sebelum tindakan menjadi rata-rata 79,7 dan ketuntasan kelas mencapai $68,75 \%$ pada akhir siklus II. Dengan demikian penerapan model CRH dapat meningkatkan hasil belajar siswa dalam pembelajaran IPA. Gain yang didapat 20,92 atau hampir sama dengan capaian penelitian ini.

Selanjutnya, penelitian Murizal, A. (2012) dengan judul Pemahaman Konsep Matematis dan Model Pembelajaran Quantum Teaching menemukan hasil nilai rata-rata hasil belajar matematika siswa kelas eksperimen yaitu 76,1 dan nilai rata-rata kelas kontrol 63,2. Data ini menunjukkan bahwa nilai rata-rata kelas eksperimen lebih tinggi dari kelas kontrol. Dengan kata lain terdapat perbedaan sebesar 12,90. Kedua penelitian ini sejalan dengan hasil penelitian ini.

\section{SIMPULAN DAN SARAN Simpulan}

Berdasarkan analisis data yang telah dilakukan terdapat perbedaan hasil belajar yang signifikan dalam penerapan model pembelajaran Course Review Horay dan model pembelajaran Quantum Teachingyang ditunjukkan dengan uji t yang menghasilkan nilai t-test sebesar -4,642 dengan probabilitas signifikan 0,000<0,05 dan pada df 48 . Terlihat pula pada rata-rata hasil belajar yang ditunjukkan dengan adanya gain score, hasil belajar matematika pada kelas eskperimen sebesar 10,08 dan kelas kontrol sebesar 24,24. Maka penelitian ini menunjukkan bahwa terdapat perbedaan hasil belajar yang signifikan dalam penerapan model pembelajaran Course Review Horay dan model pembelajaran Quantum Teaching.

Jadi dapat disimpulkan bahwa terdapat perbedaan hasil belajar yang signifikan dalam penerapan model pembelajaran Course Review Horaydan model pembelajaran Quantum Teaching dilihat dari hasil belajar matematika siswa kelas 3 Semester II Tahun Ajaran 2016/2017 di SD Kristen Satya Wacana dan SD Negeri Salatiga 6. 


\section{Saran}

Berdasarkan kesimpulan di atas, maka peneliti menyarankan beberapa hal yang perlu diperhatikan:

a. Bagi Guru

Sebagai referensi guru dalam memilih model pembelajaran yang dapat menciptakan suasana proses belajar yang menyenangkan dengan menerapkan model pembelajaran Quantum Teachingkarena sudah terbukti bahwa model pembelajaran Quantum Teachingdapat membawa siswa mendapatkan hasil belajar yang lebih baik daripada menggunakan model pembelajaran Course Review Horay.

b. Bagi Siswa

Siswa merasa senang dalam mengikuti pelajaran matematika dengan menggunakan model pembelajaran Quantum Teaching karena belajar sambil diiringi musik dan dengan suasana yang aman, nyaman dan menyenangkan sehingga siswa dapat memperoleh pencapaian hasil belajar yang memuaskan.

c. Bagi Sekolah

Sekolah akan terpacu untuk menerapkan model-model pembelajaran kreatif, seperti model pembelajaran Quantum Teaching dalam rangka meningkatkan kualitas proses pembelajaran.

\section{DAFTAR PUSTAKA}

Arnawa. 2006. Meningkatkan Kemampuan Pembuktian Mahasiswa dalam Aljabar Abstrak melalui Pembelajaran Berdasarkan Teori APOS. Disertasi. Bandung: Universitas Pendidikan Indonesia

DePorter, B. Reardon, M. Dan Nourie, S.S. 2000. Quantum Teaching: Mempraktekan Quantum Learning di Ruang-Ruang Kelas (penerjemah:Ary Nilandari). Bandung : Kaifa.

Dwitantra. 2010. Model Pembelajaran Course Review Horay (CRH).Online. Tersedia: http://cheliemarlangen.blogspot.com diakses tanggal 02 Juli 2016

Harianto. 2012. Pengaruh Startegi Pembelajaran Course Review Horay Menggunakan Puzzle Terhadap Hasil Belajar Siswa Pada Standar Kompetensi Menerapkan Dasar-Dasar Elektronika Di SMK. Jurnal Pendidikan Teknik Elektro, Volume 02 Nomor 1, Tahun 2013, 401-409 diakses tanggal 06 Juli 2016 dari http://ejournal.unesa.ac.id/article/2512/44/article.pdf

Harianto. 2013. Pengaruh Strategi Pembelajaran Course Review Horay Menggunakan Puzzle Terhadap Hasil Belajar Siswa. Jurnal: Universitas Negeri Surabaya. http://ejournal.unesa.ac.id

I Nym Adi Kurniawan, I Md Suara, I.B. Surya Manuaba. 2014. Pengaruh Model Quantum Teaching berbantuan Media Audio Terhadap Hasil Belajar IPS Siswa Kelas V Semester 1 SD Gugus 7 Sukawati, Kabupaten Gianyar Tahun Ajaran 2013/2014. Jurnal: Universitas Pendidikan Ganesha. http://ejournal.undiksha.ac.id

Indonesia. 2015. Indahnya Persahabatan: buku guru/ Kementerian Pendidikan dan Kebudayaan. Jakarta: Kementerian Pendidikan dan Kebudayaan.

Isjoni. 2010. Pembelajaran kooperatif. Yogyakarta: Pustaka Pelajar.

Kelebihan dan Kelemahan Pembelajaran Quantum Teaching. http://www.dokumen.tips diakses tanggal 08 juli 2016. 
Perbedaan Pengaruh Penerapan Model Pembelajaran Course Review Horay Dan Quantum Teaching Dilihat Dari Hasil Belajar Matematika Siswa Kelas 3 SD (Mesti Fajar Romadhoni, Stefanus C. Relmasira)

Model Pembelajaran Quantum Teaching. http://www.sekolahdasar.net diakses tanggal 08 Juli 2016.

Murizal, A. (2012). Pemahaman Konsep Matematis dan Model Pembelajaran Quantum Teaching. Jurnal Pendidikan Matematika, 1(1).

Pengertian Pembelajaran Quantum Teaching Serta Model dan Prinsipnya. http:// www.sarjanaku.com diakses tanggal 08 Juli 2016.

Permendiknas No.22 Tahun 2006. http://www.aidsindonesia.or.id diakses tanggal 08 Juli 2016

Pratiwi, L. (2011). Penerapan model course review horay (CRH) untuk meningkatkan pembelajaran IPA siswa kelas IV SDN Merjosari 1 Malang.

Rochayati. 2007. Pengaruh Metode Quantum Teaching dan Quantum Learning Terhadap Prestasi Belajar Matematika Ditinjau Dari Aktivitas Belajar Siswa (Pada Siswa Kelas III SD Negeri 20 Kota Madya Banda Aceh). Skripsi: Universitas Muhammadiyah Surakarta.

Slameto. 2010. Belajar dan Faktor-Faktor yang Mempengaruhinya. Jakarta: Rineka Cipta.

Suyatno. 2009. Penjelajah Pembelajaran Inovatif. Sidoarjo: Mas Media buana Pustaka.

Thobroni. 2016. Belajar \& Pembelajaran: Teori dan Praktik.Yogyakarta: Ar-Ruzz Media.

Wahyudi, Kriswandari. 2013. Pengembangan Pembelajaran Matematika SD. Salatiga: Widya Sari Press. 